\title{
NEPAL'S ARMED CONFLICT AND THE PEACE PROCESS
}

\section{Ram Krishna Tiwari*}

\begin{abstract}
This paper deals with the political development of Nepal and its history of armed conflict. The formation of Nepali nation-state is not very long, again throughout its political history Nepal remained an independent country, but this country experienced a decade long political conflict from 1996 to 2006. The failure of political change of 1951 and 1990 prepared a political ground for the official beginning the People's War, and after 2006 the country is moving into the path of peace process. Similarly, the formation of political parties has not a long history compared it with the beginning of democratic movement in India, China and other countries of the world. The poor political vision of the political leaders failed to institutionalize the political change of Nepal, and now the ongoing peace process of Nepal should erase all the weaknesses and conclude it for building a prosperous nation.
\end{abstract}

Key words-political development, nation-state, formation of political parties, armed conflict, formal democracy, new-modelled-democracy, peace process, political inclusion, equality and justice

\section{POLITICAL DEVELOPMENT OF NEPAL}

This paper deals with the historic conflict analysis of Nepal and its link with political changes of Nepal. The roles of political parties, civil society, and other actors and theories towards Nepalese determination would be pertinent the prominent issues in the new political development of Nepal. If we analyze the history of Nepali people, Dor Bahadur Bista views Mongoloid (hunting nomads) and Caucasoid peoples (pastoral nomads) entered to Kathmandu valley around the first millennium BC from the north-east and north-west regions. (1982: 3-5) The history of Nepali nation-state began in 1768 with the unification campaign of Kathmandu valley. Baburam Bhattrai dates the formation of the Nepalese states to the eleventh century AD. He further points out after the eleventh century huge numbers of Hindu people migrated to Nepal from Indian plains in the wake of Muslim invasions there (36).

The detribalization of the traditional state-communities which were established in Nepal after eleventh century, and new states were formed one after another in the different parts of Nepal. In the mid eighteenth century Prithivi Narayan Shah began to extend the small territorial state of Gorkha, his unification campaign annexed some 60 petty principalities to form the state of Nepal. The 
small states of Chaubise Rajya in the Gandaki region, Baise in the Karnali region, and other states in Kathmandu valley and eastern Nepal lost their independent identities and the people of those respective geographical locations became the citizens of a unified Nepal. Thapa and Sijapati express that the first stage in the formation of the Nepali nation-state was complete by 1768, when Prithivi Narayan Shah conquered the Kathmandu Valley and shifted his capital there from Gorkha (2006: 13). In a very short time Prithivi Narayan Shah and his decedents expanded the political territory up to Teesta in the east and Sutlej in the west (2003: 36), an area nearly twice the size of today's Nepal (Thapa and Sijapati, 2006).

The eco-political war between the British East India Company and Nepal in 1814-16, Nepal lost huge areas, including Teesta and Sutlej. The Sugauli treaty signed in 1816 forced Nepali rulers to abandon the political expansion of Nepal's territory resulted in the present boundaries from the Mechi River in the east to the Mahakali River in the west. With it Prithivi Nepayan Shah's descendants were unable to retain firm political control, and high-ranking royal officials involved in conspiracies that resulted in the formation of fragile Nepali nation-state. In 1846, Jung Bahadur Rana controlled the political power through a Military coup and eliminated all his enemies in the Kot and Bhandarkhal massacres in 1846 and 1847 he dethroned King Rajendra and elevated Rajendra's son Surendra Bikram Shah to the throne. In this way the Rana dynasty that Junga Bahadur initiated in Nepal in $1946 \mathrm{AD}$ remained as a political power until 1951.

\section{FORMATION OF POLITICAL PARTIES AND CONFLICTS IN NEPAL}

Even after the end of British rule in India in 1947, Nepal remained a semi-colonial country and semi-feudal country. For 104 year Nepali people made various struggle to introduce the rule of law and to establish the democratic system in Nepal. The revolt of Lakhan Thapa against Rana autocracy and other civil right movements directed to establish political rights and assert the sociopolitico-economic identities of Nepali people. For this, the first political party 'Praja Parisad' established in 1936 opposed the family-based system of Rana regime. Similarly, Nepali Congress was established in 1947, the Nepal Democratic Congress followed the path of Nepali congress in 1948, and the Ccommunist Party of Nepal was established in 1949. The political parties founded around 1950 were established in India, and due to the effect of that even at present there is a close influence of Indian politics in Nepal's political changes and instability.

By 1951, the last Rana Prime Minister Mohan Shamsher agreed to form a new government with the effect of the people's movement and it was an outcome of tripartite agreement between India, Rana and the King of Nepal. Even after that Nepal experienced political instability and the revolt of Bhim Datta Panta in western Nepal reflected the same and denied the incomplete nature of that democratic transition. In a very short time the first government got collapsed and Nepal entered into a decade-long political conflict for holding the election of 
Constituent Assembly (CA) and drafting a new constitution for a fully democratic Nepal. King Tribhuvan had already promised Nepali people to hold an election CA in 1951 but his son Mahendra, who came in power in 1955, declared the king to be the source of all political power in the Constitution of the Kingdom of Nepal 1959 and wished to hold the election of the first parliament of Nepal. In this unfair political circumstance the political parties failed to wage a struggle against the apolitical step of the palace. However, they took part in the general election of 1959, and it heightened a political struggle between the palace and the cabinet and in 1961 the King Mahendra introduced a partyless Panchayat system that ruled in Nepal for thirty years.

\section{POLITICAL HISTORY OF ARMED CONFLICT IN NEPAL}

The seed of present United Communist Party of Nepal (Maoist) was sown in 1957 when Mohan Bikram Singh was elected in the central committee of Communist Party of Nepal, and in 1961 he opposed the political lines of Keshar Jung Rayamajhi and Puspa Lal and demanded to hold the CA election. Similarly, the rise of Nirmal Lama, Mohan Baidhya, Bhakta Bahadur Shrestha and Puspa Kamal Dahal 'Prachanda' in politics led the revolutionary political movement in Nepal. In different historic period they led the left political movement in Nepal. In 1990 the political change at its superstructure could not solve the political issues and the political stalemate worsened the economic situation of Nepal and it planted the seeds of conflict that emerged in 1996 as an ideological struggle. Before this the revolt of Lakhan Thapa, Bhim Data Panta ware crushed by the rulers. However, the Communist Party of Nepal (Maoist) and now it is known as United Communist party of Nepal (Maoist) launched the People's War in 1996 to establish its own political system. In a very short time it affected the entire country for a decade. In the post-Rana period, the Communist Party of Nepal (CPN) had followed an anti-Congress position, and in a decade-long political transition from 1951 -1960 no Communist leader was nominated as the minister of Nepali government. The leaders stated that they were progressive forces and the leaders of the Nepali Congress were the stooge of the Indian government; and called upon the people to form a "people's front to fight against the Nepali Congress (Gupta, 1993: 201). The alliance of CPN with anti-Congress parties emphasized its intention to prevent Indian influence in Nepal and built friendly relations with China. The Communist leaders were divided into pro-Moscow and pro-Peking factions, and in Baral words it led to a split within the party (1977: 83.) In 1979 the new Secretary General Nirmal Lama started giving guerilla training, "proletarianizing" party cadre, and initiating an agrarian uprising. In the 1990s, the CPN (Unity Center) followed the same policies; and it changed its name to the CPN (Maoist) in 1995, and declared a "people's war" to establish its own political system in 1996.

In 1996, United People's Front led by Dr. Babu Ram Bhattrai- a senior Maoist leader- submitted its 40-point demands to the Prime Minister Sher 
Bahadur Deuba of Nepali Congress and gave a deadline to the government to fulfil all demand within 15 days. As the government failed to address the issues politically, the CPN (M) lunched the People War on 13 February 1996. The attack in police posts, government offices and Agricultural Bank was an official beginning of the People's War that drove Nepal into a decade long ideological armed conflict. Many scholars have studied the Maoist insurgency from different perspectives and Birendra Prasad Mishra points out a decade old Maoist conflicts increased the militarization in Nepal. He mentions that the comprehensive peace accord; signed by the Maoists and the government; was an end of political deadlock and formally it paved a new way to go ahead for solving the political crisis. The dialogue between the Seven Political Parties' Alliance (SPA) and the CPN (M) played major roles to solve the crisis; the political power of the feudal king was already sidelined after signing on 12-point understanding in India in 2005, and its reflection in the Comprehensive Peace Accord (CPA) of 2006.

\section{POLITICS OF PEACE PROCESS IN NEPAL}

The peace process in Nepal officially began after signing on 12-point agreement. The political parties SPA and CPN (M) had already agreed to sideline the power of king and declare the republican country. For this, Mishra views the peace process of Nepal which he has categorized the armed conflicts in different forms like political, social, cultural, ethnic and religious address the issue politically (2009: 1-2). He says that the peace process is the only mechanism for resolving the conflict. In his words peace process commenced with signing on CPA and developed to the constitution of an interim Legislature in 2007. Similarly, it entered into the monitoring of People's Liberation Army under the supervision of UNMIN. Then it formed an interim Legislature Parliament and moved to the legal process of the political change. After that the election of CA in 2008 and its first meeting legalised the all process of republican country. Unfortunately, it failed to declare a new constitution, however, the leaders have agreed the first CA had completed the almost ninety per cent of its scheduled work, and present CA which was held in 2013 has accepted the legacy of the first CA.

Nepali peace process substantially changed a political equation among the political parties and former rebel force joined in the main stream politics and headed two coalition governments in Nepal. It ultimately ended the feudal monarchical system, Nepali peace process despite its some weaknesses addressed the issues of women, accepted the identity politics of Dalit, Madeshi, indigenous people, minority groups, backward groups; and ultimately floated the issues of nationality and national security - the issue of national security is one of the agenda of peace process of the CPA 2006.

Drafting a new constitution is the main agenda of the peace process. Highlighting the entire it basically focuses on the monitoring of the weapons and combatants and Nepal Army. The positive part of the peace process is it sounds a note of caution to stakeholders to be prompt in taking suitable action for building 
a new Nepal in accordance with long-term political vision of political parties. It should address the entire political change of Nepal which ultimately should be the part of politically marginal class as well as the ignored voices of common populace should be heard formally.

Further, the role of UNMIN (United Nations Mission in Nepal) in the Nepal's peace process was vital. The Government and Maoist party requested to help from the Secretary General of the UN on 9 August 2006 by writing letters separately to him. In this regard, the Security Council responded positively to request for assistance from Nepali parties and approved the advance deployment of 35 arms monitors and 25 electoral advisers. On January 2007, in Resolution 1740, the Security Council unanimously supported the establishment of the United Nations Mission in Nepal. UNMIN was to have an initial 12 month mandate. Ian Martin who was the then Chief of the office of the High Commissioner for Human Rights (OHCHR) in Nepal and was appointed Special Representative of the Secretary-General and Head of UNMIN. This was the first UN involvement in Nepal peace process. Feyzi Ismail views Nepal's CPA signed in November 2006 between government and other major political parties and the Communist Party of Nepal (Maoist) need to continuing emphasis on economic equity and an end of poverty. If again it undermines the issues of Nepali people, Nepali would face a continuous trouble in the future.

\section{PEACE BUILDING IN NEPAL}

The history of peace building began at the end of the nineteenth century formally. With the end of Cold War and the 1992 UN Agenda for Peace, and the practice of peace building gained significant international momentum, and the focus shifted away from intra-state conflicts to the management and resolution of armed conflicts within states. Paffenholz and Spurk view peace building as an overarching term to describe a long-term process covering all activities with the overall objective of preventing violent outbreaks of conflict or sustainably transforming armed conflict into constructive, peaceful ways of managing conflict. Galtung distinguishes two forms of peace-negative and positive (1996).

Upreti quotes the ideas of Ackerman, Barenes, and Bailey and views that that peace building is a process of rebuilding a strong state to establish a political stability. It seeks to make new and normal relations among warring parties and people in conflict with each other (2006). It plays a role in rebuilding trust and cooperation in order to join together in society. To address the Nepali peace process and to come to its logical end, the stakeholders who contribute to the peace process must be addressed. The peace building process of Nepal should adopt socio-political transformation of the entire country which might be the formal democratic processes combined with the promotion of economic activities of the people. Nepal's political parties have so far failed to achieve the political goals in 1951, 1990 and now they have got a good political chance to empower the common people hat in the past. Ho-Won Jeong states that democracy can be 
consolidated with mature political conditions promoting both external and internal legitimacy (2005: 11).

In this broader view the peace-building process becomes productive with the introduction of inclusive democracy, which requires all political changes that were surfaced in 2006 makes a straight connection with the people's aspiration. The rise of Maoist rebellion in Nepal that was escalated in a very short time still proves there might be any possibility of eruption of the conflict, but in order to minimize all possibilities of violent conflict that might erupt in the future can be totally controlled by making socio-political and cultural changes of Nepali society. For this the interim constitution of Nepal has already committed to implement federal structure of the government, imparting people's rights for equality and making a just society, practice of inclusive democracy are good symptoms for recognizing all minorities and backward groups that really minimize the possible conflicts in the future. The success or failure of any peace process depends upon the social and psychological aspects of the political actors. In Nepal specifically, implementation strategies of peace process have to be based on the identification of actors and coordination of activities in various sectors within a given time frame. Consideration of the different needs faced by societies recovering from violent political conflict must be incorporated into a peace building design and it is a right time to build a justice-based country through peace process.

The peace process in Nepal was able to move forward a few steps, it lacks of response to immediate needs and local capacity building, both of which are necessary to a successful peace process. Thus, for a sustainable peace which helps the population to overcome extreme vulnerability and move towards self-sufficiency, integrative social developmental needs should be the focal point of Nepali peace process. In Nepal, empowering the common people and increasing people's capacity in different sectors such as politics, social aspect, improvement of economic production and its distribution, and cultural awareness would be the long-lasting solution for durable peace and the promotion 'new modelled-democracy'. In general sense, the completing the political process will never make any political solution, as there are multiple dynamics involved in the conflict in Nepal. The political change of 1951, when the Nepali people got rid of the 104-year-old feudal regime of the Ranas; the restoration of the democratic system in 1990that ended Panchyat system- all failed to strengthen the national identity of the country and the sovereignty of Nepali people. Now it has been a right time after signing on CPA in 2006 that concluded as a temporary political solution of a decade long armed conflict and now it should be considered the most successful political movement in the history of Nepal. The sociopolitical cultures of the Nepali leadership and their overall behaviour have to be transformed to address the political crisis of the country. 


\section{CONCLUSION}

The peace process of Nepal is widely praised for its progress, and again it has also been highly criticized for its failure to implement its promises. The peace process becomes unstable if the issues are not addressed promptly. For this, the identification of the root causes of political conflict is a must and then it demands a proper solution. To complete its formal path the concerned actors should address the root causes of conflicts and issues of inequality, injustice, political marginalization and state-domination of its people. Likewise, the overcome of the post-conflict transition building, trust within the communities must develop resilience to cope with the adverse impacts of conflict, and then create space and opportunities for peace building.

The CPN (Maoist) followed the path of peace process after signing on 12 point agreement reached between both political stake holders. The political analysts agree Nepali peace process is moving smoothly; and no major political incident is taking place here to make it failure. The success and failure of peace process lies behind the political consciousness of Nepalese political leaders. The end of the political power of royal palace forever, declaration of the federal republican Nepal, political identity of common people, sense of nationality among broad boundary have brought changes in political equation of Nepal. The UNO along with other international stakeholders have accepted the procedures of Nepali peace process which is good, but still the political parties have to do many things to complete the incomplete political course of Nepali peace process. The main thing is to declare a new constitution through the CA which is a minimum demand of Nepali people since 1951. If the political changes or achievements of a decade long armed conflict and the people's movement of 2006 are reflected in the constitution the peace process would be a success, and the country would definitely move towards the economic prosperity.

\section{WORKS CITED}

Baral, L. R. (2004). "Nepal Political Parties and Parliament." in The Unclear Roadmap: Parties and the Parliamentary Process, 8-36. New Delhi:Adroit Publications.

---. ed. (2006). Nepal Facets of Maoist Insurgency. New Delhi:Adroit Publications.

Bhattarai, B. (2003). The Nature of Underdevelopment and Regional Structure of Nepal: A Marxist Analysis. Delhi: Adroit Publications.

Bista D.B. (1982). "The Process of Nepalization." In Anthropological and Linguistic Study of the Gandaki Area in Nepal, 1-20, Institute for the Study of Language and Cultures of Asia and Africa, Tokyo.

Jeong, Ho-Won (2005). Peace Building in Post Conflict Societies: Strategy and Process. Lynne Reiner, Dulles VA.

Mishra, B. P. (2009). The Nepalese Peace Process. Kathmandu: Fine Print. 
Paffenholz, T. and Christoph, S. (2006). "Civil Society, Civic Engagement and Peace Building". Social Development Papers, Conflict Prevention and Reconstruction, paper no. 36:13-14.

Thapa, D. and Sijapati, B. (2006). A Kingdom under Siege: Nepal's Maoist Insurgency, 1996 to 2003. , Kathmandu: The Print House.

Upreti, B. R. (2006). Armed Conflict and Peace Process in Nepal: The Maoist Insurgency Past Negotiations, and Opportunities for Conflict Transformation. New Delhi: Adroit Publications. 